Article

\title{
The Analysis of a Translation of Musyakalah Verses in the Holy Quran Published by the Indonesian Department of Religious Affairs
}

\section{Yayan Nurbayan}

Department of Arabic Language, Faculty of Language and Linguistic, Universitas Pendidikan Indonesia, Jalan. Dr. Setiabudhi No.229, Bandung, Indonesia; yayanupi16@gmail.com

\begin{abstract}
Musyakalah is one of the Arabic linguistic styles included under the category of majaz. This style is commonly used in Al-Quran. The Indonesian translation of Al-Quran is a case where many of the figures of speech are translated literally, thereby causing serious semantic problems. Thus, the research problem of this is formulated with the following questions: 1) How many musyakalah ayahs are there in Al-Quran?; 2) How are the musyakalah ayahs translated, literally (harfiyya) or interpretatively (tafsiriyya)?; 3) How many ayahs are translated literally and how many are translated interpretatively?; and 4) Which translated musyakalah ayahs have the potential to raise semantic and theological problems? The corpus in this research consists of all musyakalah ayahs in Al-Quran and their translation to Indonesian published by the Department of Religious Affairs of Indonesia. The research adopted a descriptive-semantic method. The findings of this research are: 1) There are only eleven ayahs in Al-Quran using musyakalah style, namely: Alhasyr ayah 19, Ali Imran ayah 54, Annaml ayah 50, Alanfal ayah 30, Asysyura ayah 40, Albaqarah ayah 15, Almaidah 116, Aljatsiah ayah 34, Attaubah ayah 79, Annisa ayah 142, and Albaqarah 194; 2) The musyakalah ayahs translated literally are: Aljatsiah 34, Almaidah 116, Asysura 40, Annaml 50, and Alhasyr 19, whereas the musyakalah ayahs translated interpretatively are Albaqarah 194, Annisa 142, Attaubah 79, Albaqarah 15, Alanfal 30, and Ali Imran 54; 3) Of the eleven musyakalah ayahs, only Alhasyr ayah 19 that is translated correctly and does not have the potential of creating misinterpretation. Meanwhile, the interpretation of the other four ayahs can potentially cause misinterpretation or are against the basic principles of Islam. The six remaining ayahs are translated interpretatively and thus do not have the potential to be misinterpreted; 4) The findings suggest that musyakalah ayahs are more appropriately translated interpretatively. Therefore, the following is recommended: 1) Considering the different characteristics of Arabic and Indonesian languages, studies on Al-Quran translation into Indonesian should continuously be carried out; 2) In order to avoid misinterpretation, it is better that the translation of musyakalah ayahs uses tafsiriyya (interpretative) approach; 3) The harfiyya (literal) and tafsiriyya (interpretative) approaches should be developed for other styles beside musyakalah.
\end{abstract}

Keywords: Translation; musyakalah; linguistic style; holy Quran; Arabic language 


\section{Introduction}

In the science of Balaghah, there are several types of linguistic styles linked to relations between meanings. The related meanings in the context of linguistic styles include hakiki, majazi, close meaning (qarib), and distant meaning (ba'id). Hakiki meaning is the original and basic meaning of a word, or what is also called denotative meaning. Meanwhile, majazi meaning is the second or connotative meaning. Qarib literally means close meaning or similar to hakiki meaning. Finally, ba'id meaning is distant meaning, which is used in the next sentence, but does not have connotative meaning. In Arabic language, various styles are concerned with the relation between meanings, including the styles of majaz, kinayah, tauriyah, jinas, istikhdam, and musyakalah. Majaz and kinayah are the objects of bayan studies, while tauriyah, jinas, istikhdam and musyakalah are included under the studies of badie'.

Majaz is the use of a certain word intended not for its real meaning because of relation and qarinah (indicator) that the word does not mean what it actually means (Qashshab, 2012: 111). Kinayah is a phrase expressed for the conventional meaning (generally understood meaning), but it can also be understood denotatively. Majaz and kinayah have similarities and dissimilarities. The similarity lies in the fact that both should be interpreted in majazi manner (second meaning), while the difference lies in the use of hakiki meaning. Majaz cannot be interpreted in hakiki way, while kinayah may be using hakiki meaning. Meanwhile, tauriyah is a word with double meanings, namely qarib and ba'id meanings, and in this context, ba'id meaning is more appropriate. Jinas, on the other hand, is a word that is mentioned twice in the same context, but the meaning of the first mention will be different from that of the second mention. Istikhdam is a style in the form of the use of a word with two meanings. The word is used for the first meaning, but then is repeated by dhomir (pronominal) that will return to the first word, but with different meaning.

According to the literature, musyakalah is taken from the word syakl, which means similar or identical. Meanwhile, etymologically, musyakalah is

$$
\text { المشاكلة هى ان يذكر الشىء بلفظ غيره لوقوعه في صحبته. }
$$

"Uttering an expression along with another expression whose position functions as a counterbalance.” (Kafi, 2008; Maidani, 1992; Maraghi, 1991)

Meanwhile, Qashshab (2012: 47) explains that musyakalah is mentioning something not with the proper word because of its position as a counterbalance, both explicitly and implicitly. The beauty of musyakalah style lies in the model of expression and the high level of language. The reader or listener will think that the word or phrase has a meaning similar to that of the first word or phrase. However, upon closer observation and focused analysis, the reader will find that the second word has a dissimilar meaning to that of the first. This phenomenon is what makes message understanding inherent in the reader or listener.

Previously, the scholars of Balaghah argued that musyakalah was a part of majaz lughawi. According to Zaenuddin and Nurbayan (2007: 117) musyakalah is of the third type, neither belonging to the hakiki meaning nor to majazi. Musyakalah is the original linguistic style of Al-Quran and is rarely found. Musyakalah is the mediator of hakiki, majaz, and kinayah. Musyakalah can also accommodate majaz, mursal and isti'arah, as it can meet various requirements. Musyakalah also shares some similarities with jinas, the difference lies only on the type of meanings. The second 
word in jinas is interpreted literally, different from the first word; meanwhile, in musyakalah the second word is interpreted interpretatively, distinct from the meaning of the first word. From the explanations, it is clear that musyakalah is tangent with various other styles that are the areas of Balaghah studies.

The broad meanings and the various semantic aspects that have certain relation to musyakalah is in itself a problem to be solved. Therefore, this research will discuss the semantic analysis of the translation of musyakalah ayahs in Al-Quran.

Semantic is the technical term referring to the study of meaning. It is a theory of meaning, namely a systematic branch of language that investigates meanings. (Pateda, 1989: 12). In addition, Tarigan (1995: 7) says that semantic is the analysis of meaning. It analyzes symbols or signs that state the relation of one meaning to another and its influence on human and the society. Therefore, semantics encompasses word meaning, its development and changes.

In semantic study, there are two components: 1) The components that make meaning, in the forms of linguistic sounds, and 2) The components that are interpreted from the meanings of the first component(s). Both components are signs or symbols, while what are signed or symbolized are what exist outside the prevalent language, or called referent (Abdul Chaer, 1989: 2).

There are three ways employed by linguists and philosophers in their efforts of explaining meanings in human language, namely a) By giving the essential definition of the word; b) By defining the essential meaning of sentences; c) By explaining the communication process. In the first manner, the meaning of the word is taken as a construct, in which the meaning of sentence and communication can be explained. In the second way, the meaning of sentence is taken as the basis, while words are understood as systematic contributors of the sentence's meanings. In the third manner, both the meanings of sentence and words are explained in their limited use in the communication act (Wahab, 1995: 9).

According to Muhammad Ahmad Abul Faraj (1966) in his book Al Maajim Al Lughawiyyah fi Dhaoi ilmil Lughahtil Haditsah, meaning is divided into three types, namely: a) lexical meaning, namely the meaning restricted by linguistic sounds. Sound changes have an implication in meaning changes. The same is true for positional changes that will affect meanings; 2) siyaqi (contextual meaning), is the meaning used in a context of utterance; 3) ijtima'I (social meaning), which is the meaning of words understood by an individual in a society. All members of the community understand and have learned the meanings since early age.

The interpretation of musyakalah expressions-just like majaz-often causes conflicts among linguists, ultimately in relation to the theme of God. The same is true for musyakalah style that is identical to majaz. The only difference is that almost all linguists share a similar view on musyakalah. In this research, musyakalah ayahs in Al-Quran will be analyzed in terms of their Indonesian translation. The problems in this research are formulated into the following questions: 1) How many musyakalah ayahs are there in Al-Quran?; 2) How are the musyakalah ayahs translated, literally (harfiyya) or interpretatively (tafsiriyya)?; 3) How many ayahs are translated literally 
and how many are translated interpretatively?; and 4) Which translated musyakalah ayahs have the potentials to raise semantic and theological problems?

\section{Research Method}

The research was conducted to reveal the essence of linguistic expression of musyakalah in Al-Quran and the Indonesian translation. By finding about the essence of musyakalah style, it is expected that the research can contribute to the development of translation theory, more specifically the translation of musyakalah ayahs in Indonesian. The literal translation of Al-Quran's musyakalah ayahs can trigger interpretation problems among readers. In addition, the literal translation of these ayahs is not in accordance with the appropriate aqidah and can encourage the readers to misinterpret the ayahs. Therefore, correct translations should be found, ones that do not violate the rules of Arabic and the essence of religion.

\section{Research Corpus}

In this research, data is divided into primary and secondary data. The primary data is the sources of data made as the object of study, namely the ayahs of AlQuran using musyakalah style and their translations in Indonesian. Meanwhile, the secondary data are in the form of interpretation books which provide additional data and explanations for the primary data. The books consist of Alkasysyaf by Fakhruddin Arrazi and Almunir fil Aqidah qasysyari'ah wal manhaj by Wahbah Zuhaili. These two exegeses are quite adequate to reveal musyakalah ayahs, considering the two mufassir (commentators) have conducted a large number of linguistic studies.

\section{Research Stages}

The main object of this research is Al-Quran ayahs using musyakalah style. The ayahs are needed as the text, without disregarding their position as Allah's commands. As the object of this research is text, the research can be categorized as qualitative research.

The research attempts to describe the translations of Al-Quran ayahs using the musyakalah linguistic style. More specifically, the stages taken in this research are: 1) Identifying the -ayahs of Al-Quran using musyakalah style; 2) Explaining the translations of the ayahs employing musyakalah; 3) Analyzing the translations of musyakalah ayahs by looking at the translation method; and 4) Analyzing the differences in the translation methodologies and their implication on the semantic meanings.

\section{Findings}

\section{Musyakalah ayahs in Al-Quran}

Al-Quran is the holy book that was born when the Arabic people were admiring the prominence of literature. Therefore, Al-Quran serves as guidance for human beings and has the miracle of competitive force and the power to defeat something that used to be the pride of the Arabic people in that era, namely the sublimity of literature. Al-Quran is not a literary book, but it has high literary value. The sublime language has been acknowledged by the people during the era of its birth. In the beginning of its revelation, many people admired the language of Al-Quran and therefore decided to embrace Islam. Their great concern of the 
sublime language of Al-Quran that could attract the Arabs, the social figures of Quraish banned their family members and friends to listen to Al-Quran recitation.

The clerks of ulumul quran admitted that the language of Al-Quran contains the sublime value of literature. It contains various linguistic styles commonly used by the Arabs at that time. Various linguistic styles, such as tasybih, majaz, isti'arah, kinayah, ijaz, jinas, musyakalah, and the like can be found in Al-Quran.

Musyakalah is one of the linguistic styles found in Al-Quran. From the analysis of Al-Quran ayahs using the musyakalah style, fourteen ayahs are found, namely surah Alhasyr ayah 19, Ali Imran ayah 54, Annaml ayah 50, Alanfal ayah 30, Asysyura ayah 40, Albaqarah ayah 15, Almaidah 116, Aljatsiah ayah 34, Attaubah ayah 79, Annisa ayah 142, and Albaqarah 194. The ayahs can be seen in more detail in the following table:

\begin{tabular}{|c|c|c|c|}
\hline No & $\begin{array}{c}\text { Chapter and } \\
\text { Ayah }\end{array}$ & Musyakalah Ayahs & Indonesian Translations \\
\hline 1 & $\begin{array}{l}\text { Alhasyr ayah } \\
19\end{array}$ & نَسُوا اللَّة فَأَنْسَاهُهمْ أَنْفُسَهُهُمْ & $\begin{array}{l}\text { Dan janganlah kamu seperti orang- } \\
\text { orang yang lupa kepada Allah, lalu } \\
\text { Allah menjadikan mereka lupa } \\
\text { kepada diri mereka sendiri. } \\
\text { (And, be not like those who forgot } \\
\text { Allah, as a result Allah caused them } \\
\text { to forget themselves, it is they who } \\
\text { are the transgressors.) }\end{array}$ \\
\hline 2 & $\begin{array}{l}\text { Al Imran ayah } \\
54\end{array}$ & وَمَكَرُوا وَمَكَرَ اللَّهُ وَاللَّهُ خَيْرُ الْمَاكِرِينَ & $\begin{array}{l}\text { Orang-orang kafir itu membuat tipu } \\
\text { daya, dan Allah membalas tipu daya } \\
\text { mereka itu. Dan Allah sebaik-baik } \\
\text { pembalas tipu daya. } \\
\text { (The disbelievers schemed, and } \\
\text { Allah schemed against them. And } \\
\text { Allah is the best of schemers.) }\end{array}$ \\
\hline 3 & $\begin{array}{l}\text { Annaml ayah } \\
50\end{array}$ & وَمَكَرُوا مَكُرًا وَمَكَرْنَا مَكْكرًا & $\begin{array}{l}\text { Dan merekapun merencanakan } \\
\text { makar dengan sungguh-sunguh dan } \\
\text { Kami merencanakan makar (pula), } \\
\text { sedang mereka tidak menyadari. } \\
\text { (So they plotted a plot: and We } \\
\text { plotted a plot (too), while they } \\
\text { perceived not.) }\end{array}$ \\
\hline 4 & $\begin{array}{l}\text { Alanfal ayah } \\
30\end{array}$ & وَيَكْكُرُونَ وَيْكْكُرُ اللَّهُ وَاللَّهُ خَيْرُ الْمَاكِكِينَ & $\begin{array}{l}\text { Mereka memikirkan tipu daya dan } \\
\text { Allah menggagalkan tipu daya itu. } \\
\text { Dan Allah sebaik-baik pembalas tipu } \\
\text { daya. }\end{array}$ \\
\hline
\end{tabular}




\begin{tabular}{|c|c|c|c|}
\hline & & & $\begin{array}{l}\text { (They planned - and Allah also } \\
\text { planned - Allah is the best planner of } \\
\text { all.) }\end{array}$ \\
\hline 5 & $\begin{array}{l}\text { Asysyura ayah } \\
40\end{array}$ & 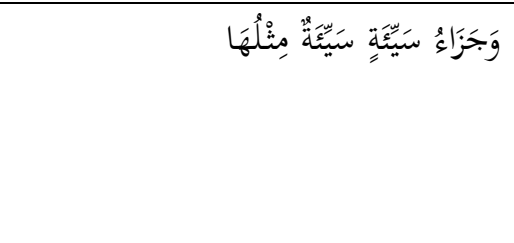 & $\begin{array}{l}\text { Dan balasan suatu kejahatan adalah } \\
\text { kejahatan yang serupa, } \\
\text { (The recompense for an injury is an } \\
\text { injury proportionate to it) }\end{array}$ \\
\hline 6 & $\begin{array}{l}\text { Albaqarah } \\
\text { ayah 14-15 }\end{array}$ & 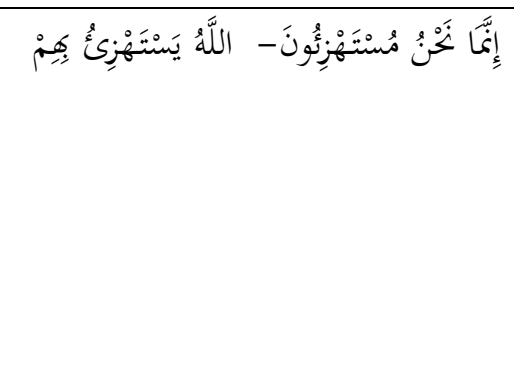 & $\begin{array}{l}\text {...Kami hanya mengolok-ngolok } \\
\text { saja (14). Allah akan (membalas) } \\
\text { olok-olok mereka. } \\
\text { (. . . verily we did but mock [14]. } \\
\text { God will [requite] them for their } \\
\text { mockery) }\end{array}$ \\
\hline 7 & Almaidah 116 & 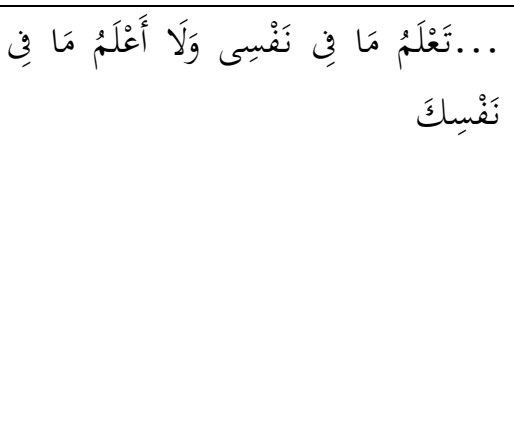 & $\begin{array}{l}\text {... Engkau mengetahui apa yang ada } \\
\text { pada diriku, dan aku tidak } \\
\text { mengetahui apa yang ada pada diri } \\
\text { Engkau... } \\
\text { [. . . You know what is in my heart, } \\
\text { and I know not what is in Yours... } \\
\text {.] }\end{array}$ \\
\hline 8 & $\begin{array}{l}\text { Aljatsiah ayah } \\
34\end{array}$ & 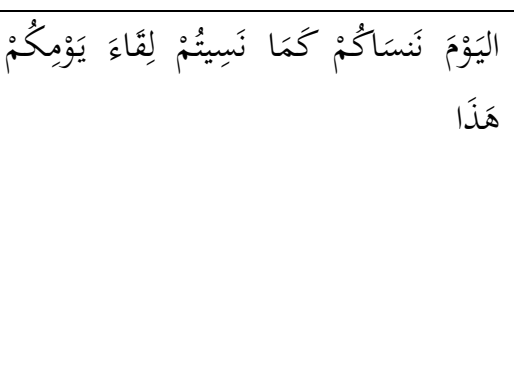 & $\begin{array}{l}\text { Pada hari ini Kami melupakan kamu } \\
\text { sebagaimana kamu telah melakukan } \\
\text { pertemuan (dengan) harimu ini. } \\
\text { (Today We will forget you as you } \\
\text { forgot the meeting of this Day of } \\
\text { yours) }\end{array}$ \\
\hline 9 & $\begin{array}{l}\text { Attaubah ayah } \\
79\end{array}$ & فَيَسْخَرَرُونَ مِنْهُمْ سَخِرَ اللَّهُ مِنْهُمْ & $\begin{array}{l}\text {... maka orang-orang munafik itu } \\
\text { menghina mereka. Allah akan } \\
\text { membalas penghinaan mereka itu, } \\
\text { dan untuk mereka azab yang pedih. } \\
\text { (. . so the hypocrites ridicule } \\
\text { them. Allah will throw back their } \\
\text { ridicule on them and they shall have } \\
\text { a painful punishment.) }\end{array}$ \\
\hline 10 & $\begin{array}{l}\text { Annisa ayah } \\
142\end{array}$ & إِنَّ الْمُنَافِقِينَ يُنَادِعِونَ اللَّةَ وَهُوَ خَادِعُهُمْ & $\begin{array}{l}\text { Sesungguhnya orang-orang munafik } \\
\text { itu menipu Allah, dan Allah akan } \\
\text { membalas tipuan mereka }{ }^{364} \text { ). } \\
\text { (Surely the hypocrites deceive Allah, }\end{array}$ \\
\hline
\end{tabular}




\begin{tabular}{|c|c|c|c|}
\hline & & & $\begin{array}{l}\text { and Allah will revert their deception } \\
\text { to them) }\end{array}$ \\
\hline 11 & $\begin{array}{l}\text { Albaqarah } \\
\text { ayah } 194\end{array}$ & 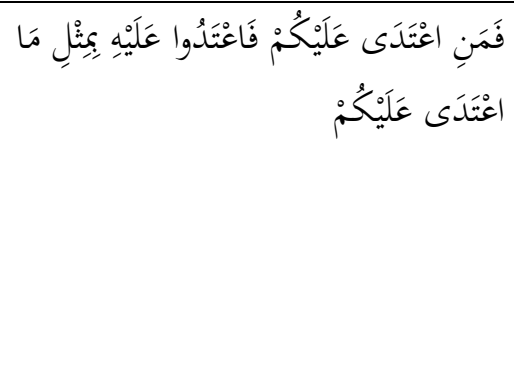 & $\begin{array}{l}\text { Barangsiapa yang menyerang kamu, } \\
\text { maka seranglah ia, seimbang dengan } \\
\text { serangannya terhadapmu. } \\
\text { (If anyone commits aggression } \\
\text { against you, attack him just as he has } \\
\text { attacked you) }\end{array}$ \\
\hline
\end{tabular}

Source: Extracted from Hosen (1989)

\section{Discussion}

1. The use of the sentence of "Allah menjadikan mereka lupa kepada diri mereka sendiri" (Allah caused them to forget themselves, it is they who are the transgressors).

The sentence above is found in surah Alhasyr ayah 19, which is a translation of

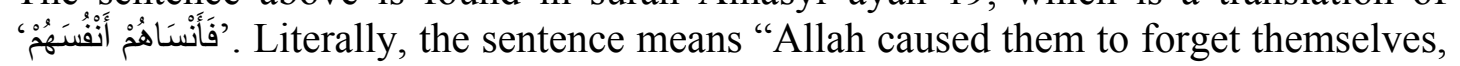
it is they who are the transgressors". The real meaning is the substitute of the sentence "Allah ignores them". The word 'أنسى' in this ayah is interpreted as 'أهمل'. The use of the word 'أنسى'which means 'أنهل' is to balance the previous sentence, namely 'نَسُو ا اللَّهُ 'The linguistic style used is musyakalah. The translation of the above ayah adopts the method of harfiyya or literal translation, which is in line with the explicit words in the ayah. However, the translation of the above ayah does not cause any semantic problem and does not violate the tauhid principles.

According to Zamakhsyari (1096), people who forget Allah SWT (subhaanahu wata'ala) have ignored two things, namely Allah and they themselves. Hence, on Judgment Day they will be ignored by Allah. This is a warning for human beings not to take for granted their obligations, ignore the consequences of the action, be too immersed in the worldly life, and pursue their passions. These people act as if they could not distinguish heaven from hell and the inhabitants of the two places. The successful people are the inhabitants of heaven, namely those who have fulfilled their obligations, abide by Allah's commands, and stay away from what is prohibited by God.

2. The use of "Allah membalas tipu daya mereka" (Allah schemed against them)

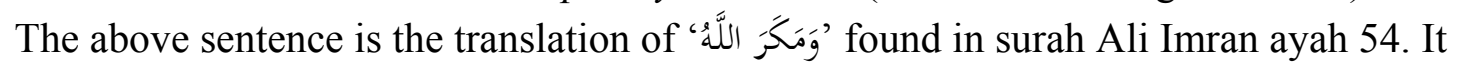
is a tafsiriyya or interpretative interpretation. The word ' deceive. Meanwhile, etymologically it means the scheme that put other people at a disadvantage. The action does not deserve to be affiliated to Allah SWT, except by employing musyakalah. The first word of ' 'َ'خ ' is the essential word, and the second word of 'مَكَ' means 'الجزاء' (the return for the scheme they have made). The use of 'کَ', alone in the second sentence is in the form of musyakalah, as the 
counterbalance of the first sentence. The word 'مَ'خر' is borrowed to mean 'الجزاء', aimed to mean that scheming will negatively affect the people who do it.

3. The use of "Dan merekapun merencanakan makar dengan sungguh-sungguh dan Kami merencanakan makar (pula), sedang mereka tidak menyadari" (So they plotted a plot: and We plotted a plot (too), while they perceived not).

This ayah is contained in surah Annaml (ayah 50), which is concerned with the event of Prophet Shalih AS who invited his people to worship Allah. Some of them joined the Prophet, while some others rejected the invitation. The disbelievers asked Shalih to send $a d z a b$ (punishment) from God, if he was truly the representative of Allah. Shalih asked his people, why they asked for punishment instead of blessing from God. These people then plotted to kill the Prophet and his followers, but Allah sent punishment to them.

In this ayah, there are two phrases using the word 'مكر' which means plotting, namely

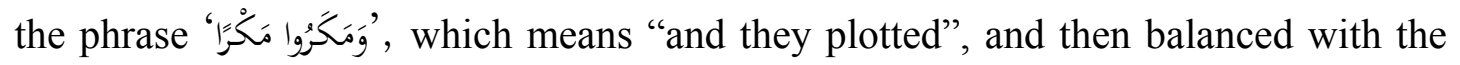

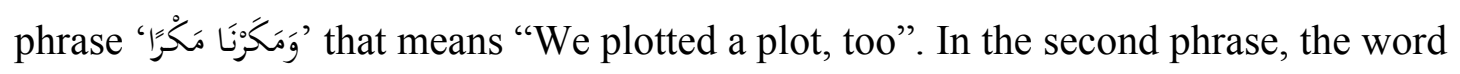
'مكر' is used. This word linguistically means planning bad deeds secretly. Still in the same phrase, the word 'مكر' is associated with Allah, so that the meaning is no longer a plot, but an adzab (punishment) for those who have plotted against Allah and His Prophet. The use of the word 'مكر' with the aforementioned meaning is a form of musyakalah or the balancer of the word in the previous sentence or phrase (Zuhaili, 2009: 246-347).

This translation is harfiyya in nature and can create an impression that Allah plots a plot. Plotting is a bad deed and is not appropriate to be associated with Allah. If the ayah is translated literally, semantic and theological problems will arise.

4. The use of "Allah menggagalkan tipu daya mereka. Dan Allah sebaik-baik pembalas tipu daya" (The disbelievers schemed, and Allah schemed against them. And Allah is the best of schemers)

The sentence is the translation of 'وَيَكْكُرُ اللَّهُ وَاللَّهُ خَيْرُ الْمَاكِرِينَ found in surah Alanfal ayah 30. The translation is tafsiriyyah, which is a translation that does not refer to the words contained in the text. This kind of translation is very good and appropriate, as it will not cause any semantic and theological problem.

The adjectives that are not appropriate to be associated with Allah are only found in the style of musyakalah. Essentially, the adjectives or attributes are not associated with Allah. The use of the word 'المكر' which means scheme in the ayah is basically not associated with Allah, and Allah is free of the attributes. Therefore, to associate the word 'المكر' with Allah entails a different interpretation that Allah will avenge the people for their schemes with punishment that is caused by their own deeds.

5. The use of "Dan balasan suatu kejahatan adalah kejahatan yang serupa" (The recompense for an injury is an injury proportionate to it) 


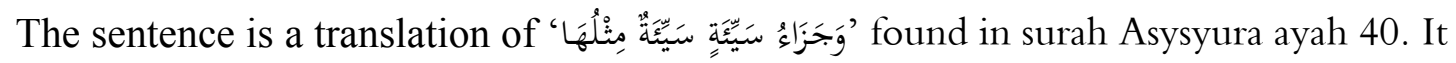
means Allah will repay people's deeds commensurately. Basically, it is not the case for Allah. The recompense is punishment and a part of the effort to realize justice, an appropriate trigger for those who disobey Allah's commands. Allah's deeds in repaying the evil deeds of evil people are not called evil or injury. The use of the

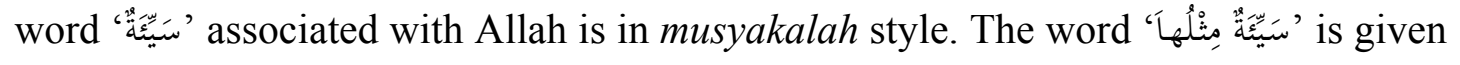
to balance the previous word that is similar and essential. The first word of '

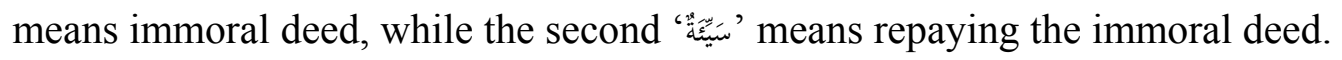

The above translation is harfiyya (literal) and can potentially trigger semantic and theological problems. This is so because when one does injury or evil deeds, s/he will then be punished according to his or her deeds. The punishment is not called injury or evil deed.

According to Thabataba'i (1997, Volume 18: 56), the linguistic style is majaz mursal with alaqah sababiyyah. People who do evil deserve to receive evil deeds. The use of

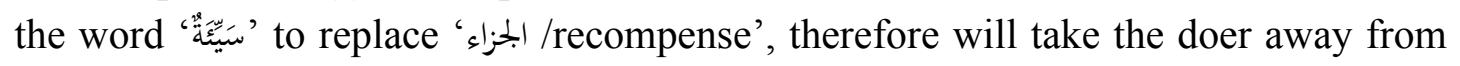
attempts of doing evil and hurting him/herself, because his or her soul will reject evil treatment. Recompensing evil deeds essentially is not an evil deed/injury, because it is the just recompense for the evil deed. The act of recompensing injury is called injury, as it is basically an injury. A perfect human being will forgive the injury inflicted by others. Forgiving is far more perfect and important than recompensing.

6. The use of "Allah akan (membalas) olok-olok mereka" (Allah will [requite] them for their mockery)

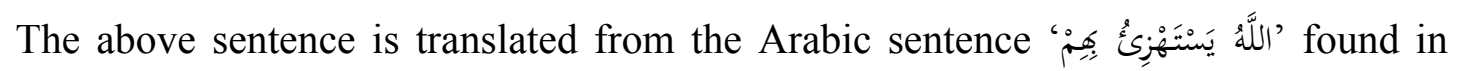
surah Albaqarah ayah 15. The translation is categorized as tafsiriyya, as it does not rely on the words in the text. The sentence cannot be interpreted as it is, but it should be interpreted that Allah requites people who mock Him with abjection and shame. Allah is the Most Holy Being and is free of any bad attribute, including mockery. The use of fi'il mudhari in the convention of Arabic language means hal (the present); it does not refer to any inherent attribute. Fi'il mudhari also contains the meaning of istiqbal (the future), which means in the Judgment Day those who mock Allah and the believers will receive the consequences and punishment in the form of shame,

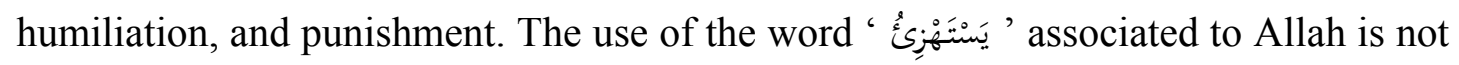

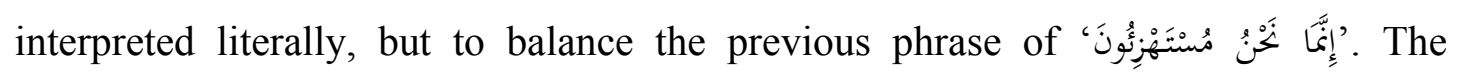
expression is called musyakalah. Zuhaili (2009: 93) in his exegesis explains that in addition to using the musyakalah style, the word has muqaranah meaning, a comparison of two actual things.

The tafsiriyya translation, as is found in the Al-Quran translation published by the Indonesian Department of Religious Affairs, does not cause semantic and theological problems. 
7. The use of "Engkau mengetahui apa yang ada pada diri-Mu, dan aku tidak mengetahui apa yang ada pada diri Engka" (You know what is in my heart, and I know not what is in Yours)

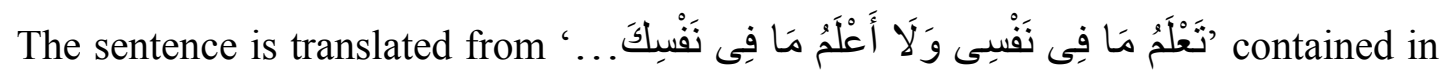
surah Almaidah ayah 116. The translation employs harfiyya method, as it explicitly refers to the words in the text. The word 'النَّْْس ', which means heart or soul is used to refer to the mind and what is inside human beings. The term human is commonly used to refer to human soul and body or substance. The meaning of the sentence 'Engkau mengetahui apa yang ada pada diriku' is "You know what I believe and I know not". The use of "النَّفْن which means soul/mind is sensible because the

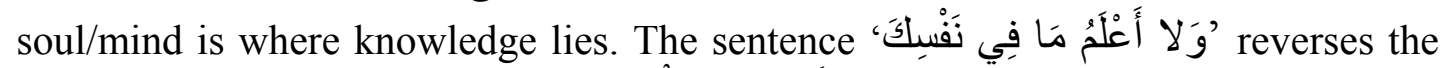
meaning of the previous sentence 'تَعْلَمُ مَا فِي نَفْسِي. The use of both sentences in the same context and place aims to unite both. More particularly, it aims to show the special features of the "substance" of Allah that is different from His beings. The combination of 'نفس' and 'الهَ' means the knowledge that Allah has is never known by others. I (Jesus) do not know what You know. The above Quranic expression is very beautiful, using musyakalah style.

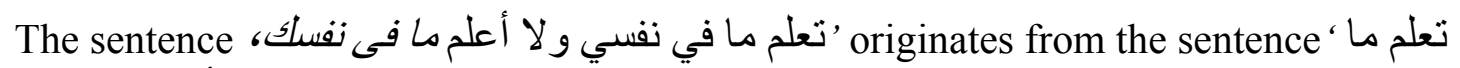

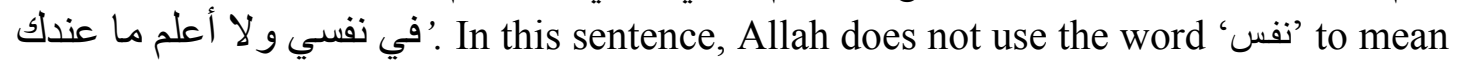
what it really means, but as a comparison for the previous phrase. The meaning of the excerpt is 'You know the essence of my substance (body) and what accompanies it, while I do not know yours and all that it encompasses, which is the attribute of perfection. You know what is hidden, what is inside a servant, and Your knowledge encompasses anything that has and has never existed, and the essence of the existence itself." The original sentence is “تعلم ما في نفسي ولا أعلم مـا عندك. The word 'نفس is not used to refer to Allah SWT, except for the sentence using musyakalah.

Zamakhsyari (2009) argues that the meaning of this ayah is " $\mathrm{O}$, God the Most Holy, may you be purified of anything associated with You. It is not my place to say something that is not the right of my heart and soul. You know my knowledge and I do not know Your knowledge." This is musyakalah style, as can be observed in the

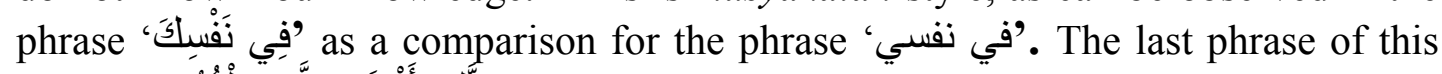

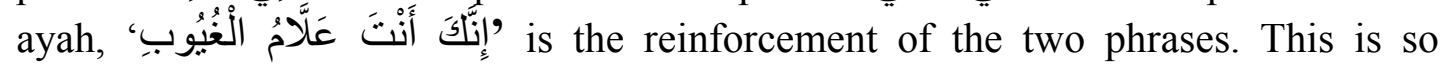
because things pertaining to the soul are ghaib (unseen) matters, known only by Allah the Most Knowing of the unseen, which cannot be known by anyone.

The translation employs the harfiyya method, or translating the text as it is. Such a translation will give an impression that Allah has a soul, just like human beings do. This understanding can cause mujassimah, which is very much in opposition with the view of tauhid clerks.

\section{The use of "Pada hari ini Kami melupakan kamu" (Today We will forget you)}

The sentence is a harfiyya translation of 'اليَوْمَ نَسَسَاكُمْ ' found in surah Aljatsiah ayah 34.

The word 'النسيان' in its general meaning cannot be associated with Allah SWT. The sentence means that Allah will requite and punish the disbelievers in hell because 
they were ignorant of Allah's commands on Earth. The use of the word 'النسيان' associated with Allah to mean to requite and punish the disbelievers in the Hereafter aims to counterbalance the subsequent sentence: 'كَمَا نَسِيتُمْ لِقَاءَ يَوْْكُمْ هَنَ'. This is a form of musyakalah. Allah SWT is free of forgetfulness as is revealed in surah Albaqarah 255.

According to Thabari (1990, Volume 21: 108), the above sentence means today we let you all be in hell, as the recompense for your previous deeds, in which you did not prepare yourself with good deeds for today's meeting.

Meanwhile, according to Zamakhsyari (2008: 1008) the sentence means later in the Hereafter, Allah will let the disbelievers in humiliation and punishment, as a recompense for their ignorance of Allah SWT during their life on Earth. They are likened to abandoned and un-useful objects, just how they have forgotten, ignored, and not paid any attention to Allah SWT. They forget the Hereafter like they forget the things they throw away and never to be remembered again.

The translation of surah Aljatsiah 34 above seems to use the harfiyya method. This translation needs further explanation in order to avoid misinterpretation because Allah does not possess the attributes of forgetfulness and drowsiness.

9. The use of "Allah akan membalas penghinaan mereka" (Allah will throw back their ridicule on them)

This sentence is a tafsiriyya translation of ' سَخِرَ اللَّهُ مِنْهُمْ found in surah Attaubah ayah 79. This ayah is concerned with the event happening to the Prophet's friend. One day, the Prophet invited his companions to make sodaqah (charity). One of the companions, Abdurrahman bin Auf, went to see the Prophet. He said, "I have eight thousand dirhams. Four thousands of it I claim for Allah, and the rest is for my family." The hypocrites insulted and ridiculed Abdurrahman bin Auf, arguing that he

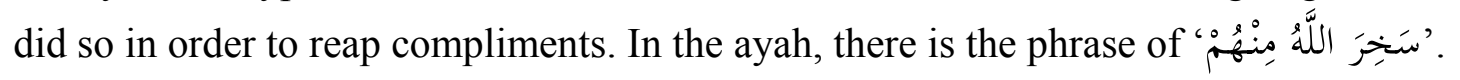
Lexically, it means Allah ridicules the hypocrites. This is definitely not appropriate, as it is not in line with what Allah has explained in Al-Quran that Allah is purified from any bad attribute. The use of ' سخر' associated with Allah SWT should be interpreted that Allah will recompense the arrogance and ridicule of these hypocrites on Earth. This recompense is a form of His justice. The association of the word ' with Allah in this ayah is due to its position to balance the previous sentence which

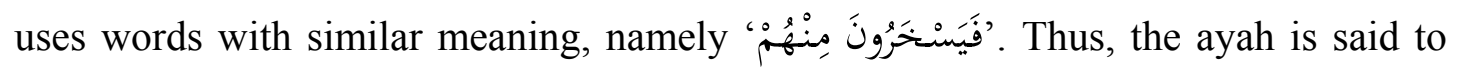
employ musyakalah.

10. The use of "Allah membalas tipu daya mereka" (Allah will revert their deception to them)

The above sentence is a translation of 'وَهُوَ نَادِعُعُمَم ' found in surah Annisa ayah 142. The ayah talks about the hypocrites. Here, Allah explains that He lets them confess as 
being Muslim, which has allowed them to be served as Mukmin. With this action, Allah has prepared hell for them as a recompense for their deception. These people display the trait of riya, namely doing a deed not in order to gain Allah's acceptance, but instead to gain compliments or popularity in the society. They worship Allah only occasionally, namely when there are people watching. In this ayah, there is a phrase

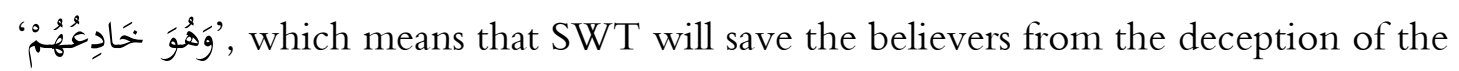
hypocrites. Allah will warn them of the hypocrites' tricks, intrigues, and plots. The second word "خَادعُعُمْم" associated with Allah SWT means Allah SWT reverts their deception, and the harm of this deception will return to them. The meaning of the word 'الخداع' is a response to the first word 'الخداع', which is the essential word. The translation of surah Annisa ayah 142 uses tafsiriyya method, so that no theological problem will arise.

11. The use of "Dan seranglah mereka seperti mereka menyerangmu" (attack him just as he has attacked you)

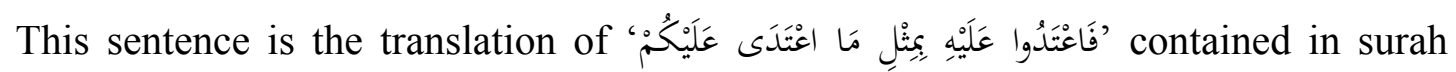
Albaqarah 194. The translation employs tafsiriyya approach. The ayah was revealed in conjunction with the event before the Hudaibiyah agreement, when Muslim people intended to conduct umrah (a shortened form of hajj) qadha, which was previously delayed because of the ban issued by Quraish people. The Quraish disbelievers banned Muslim people from practicing umrah. They were even ready to wage a war against Muslim people, if Muslim insisted on going. The event took place during Dzulqa'dah month, a respectful month, where war is not allowed. If the disbelievers continued to attack Muslim people, then it is not wrong for the Muslim people to

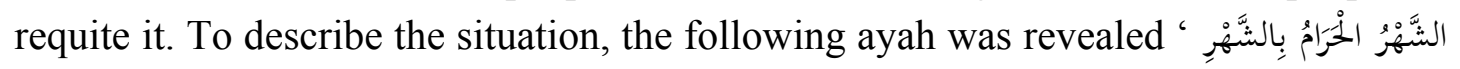

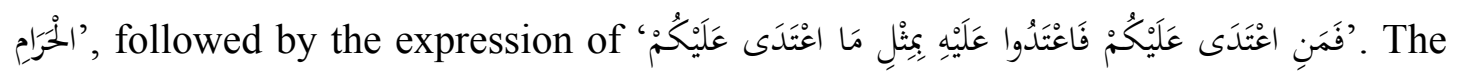
sentence means that if they (the disbelievers) wage a war against you, attack them just as how they have attacked you. The sentence uses the word 'اعتَدَّ' associated with the disbelievers and Muslim people. The association of the word with Muslim people means that the Muslim people are allowed to counterattack. This is selfdefense, not an attack, and is not something that can taint the holy month. In addition, this does not cross the boundary. The use of this word associated with Muslim people employs the musyakalah style (Zamakhsyari, 2009: 117).

\section{Contribution of Research Findings towards the Development of Translation Theory}

The Indonesian term for translation, terjemah, is taken from an Arabic word, tarjamah. Arabic language also borrows the word from Armenian, turjuman (Didawi, 1992: 37). The word turjuman is in the same form as tarjaman and tarjuman, which means transferring an utterance from one language to another language (Manzhur, n.d.: 66). 
Meanwhile, Qhaththan, Manna (1973) defines translation as follows: "Translation is explaining the source speech or observing the composition." Catford adds (1965: 20) saying, "Translation is replacement of textual material in one language (SL) by equivalent textual material in another (TL) ".

According to Az-Zarqani (677) in his book Manahilul Irfan, there are two types of: harfiyya and tafsiriyya translations. Essentialy, there are no differences between harfiyya and tafsiriyya translations.

From the above definitions, it can be inferred that: 1) Translation aims to transfer a message from a source language to a target language by finding equivalents of forms in both languages; 2) As text is what is translated, then translation also means the replacement of source language text with the equivalent target language text. The latter definition implies that translation is commonly done not at the level of sentence, but at the level of discourse.

Experts do not only differ in their opinion of translation, they also have different views of and terms for types of translation. Az-Zarqani (1411) divides translation into two types, namely: 1) Harfiyya translation, which is a translation that is concerned with the similarities to the original text in terms or arrangement and order. Such translation is made by locating synonyms or similar words from the original language; and 2) Tafsiriyya translation, namely a translation that does not pay attention to the similarities to the original text in terms of arrangement and order, but most importantly describes the meaning and aims well and perfectly.

Mansyur and Setiawan (2002), in relation to Al-Quran translation, state that for certain ayahs, harfiyya translation is prohibited, ultimately if it will cause changes in the meaning. Tafsiriyya method is more appropriate, because translation is essentially the transfer of meaning from the origin language to the target language. This means that translation must be complete and cannot change the intended meanings.

In addition, according to Syihabuddin (2005: 3), there are four obstacles in the translation of Arabic texts into Indonesian, which are: 1) The translation itself that is hard; 2) substantial difference between Indonesian and Arabic languages; 3) translator's lack of mastery of the target language, thereby causing the symptom of interference; and 4) translator's lack of knowledge of translation theory.

The translation process involves various academic aspects in order for the translation to function at its fullest. The aspects cover translation method, mastery of two languages or more, mastery of the field of knowledge to be translated, and other related things.

A translator's mastery of two or more languages, in particular, gives birth to a sociolinguistic system known as bilingualism that is caused by a contact of two languages. In relation to the translation of Al-Quran, this bilingualism entails Arabic and Indonesian languages.

The analysis on musyakalah ayahs translation in the translated Al-Quran published by Indonesian Department of Religious Affairs shows that there are two types of translation, namely harfiyya and tafsiriyya. The five musyakalah ayahs translated 
with harfiyya method are: Aljatsiah 34, Almaidah 116, Asysura 40, Annaml 50, and Alhasyr 19. Meanwhile, the six musyakalah ayahs translated with tafsiriyya method are Albaqarah 194, Annisa 142, Attaubah 79, Albaqarah 15, Alanfal 30, and Ali Imran 54.

Of the five literally translated musyakalah ayahs, only four bear the potential for misinterpretation or even violate the basic principles of Islam that are taken from AlQuran and Hadith as the resources. Only one ayah that is literally translated, namely surah Alhasyr ayah 19, that does not have the potential for misinterpretation. On the other hand, the musyakalah ayahs translated with tafsiriyya method are properly translated and thereby do not pose any problems of misinterpretation or violation of basic Islamic principles. Based on this analysis, it is recommended that musyakalah ayahs be translated with the tafsiriyya method.

\section{Conclusion}

From the findings on musyakalah ayahs and their translation in the book published by the Indonesian Department of Religious affairs, it can be concluded that:

There are 11 ayahs of Al-Quran employing musyakalah style, namely: Alhasyr ayah 19, Ali Imran ayah 54, Annaml ayah 50, Alanfal ayah 30, Asysyura ayah 40, Albaqarah ayah 15, Almaidah 116, Aljatsiah ayah 34, Attaubah ayah 79, Annisa ayah 142, and Albaqarah 194.

Five musyakalah ayahs are translated literally (harfiyya), which are: Aljatsiah 34, Almaidah 116, Asysura 40, Annaml 50, and Alhasyr 19. Meanwhile, there are six musyakalah ayahs translated interpretatively (tafsiriyya), namely: Albaqarah 194, Annisa 142, Attaubah 79, Albaqarah 15, Alanfal 30, and Ali Imran 54.

Of the eleven musyakalah ayahs translated literally, only Alhasyr ayah 19 that is translated correctly and does not have the potential of creating misinterpretation. Meanwhile, the interpretation of the other four ayahs can potentially cause misinterpretation or are against the basic principles of Islam, and the six remaining ayahs are properly translated with tafsiriyya or inrepretative method and will not potentially cause misinterpretation. Considering the finding in point 3 , the most appropriate method of translating musyakalah ayahs is tafsiriyya.

\section{References}

Abul Faraj, Muhammad Ahmad. 1966. Almaajiul Arabiyyah fi Dhaii Ilmillughah Alhaditsa. Beirut: Darulfikr

Catford, C.J. 1965. A Linguistic Theory of Translation. Oxford: Oxford University Press.

Chaer, Abdul. 1989. Pengantar Semantik Bahasa Indonesia (Introduction to Indonesian Semantics). Jakarta: Rineka Cipta

Didawi, M. 1992. Ilmut Tarjamah bainan Nazhariyyah wat Tatbiq. Tunis: Darul Maarif liththiba'ah Wannsyr.

Hosen, Ibrahim.1989. Alquranul Karim dan Terjemahnya (A1-Quran and its Translation). Jakarta: Departemen Agama Republik Indonesia.

Kafi, Umar bin Alawi. 2008. Albalaghah: Ma'ani, Bayan, Badie. Beirut: Darul Minhaj. 
Maidani, Abdurrahman Hasan. 1992. Albalaghah Alarabiyyah: Ususuha, Ulumuha wa Fununuha. Damaskus: Darul Qolam.

Mansyur dan Kustiwan. 2002. Dalilul Katib wal Mutarjim. Jakarta: Moyo Segoro Agung.

Manzhur, I.1300 H. Lisanul Arab. Beirut: Dar Shadir.

Maraghi. 1991. Fil Balaghatil Arabiyyah: Ilmul Badi. Beirut: Darul Ulumil Arabiyah.

Pateda, Mansoer. 2001. Semantik Leksikal (Semantic Lexical). Jakarta: Rineka Cipta.

Qashshab, Walid Ibrahim. 2012. Albalaghah Alarabiyyah: Ilmul Badi. Damaskus: Darulfikr.

Qhaththan, Manna.1973. Mabahits fi Ulumil Quran. Beirut: Darul Fikri

Syihabuddin.2005. Penerjemahan Arab Indonesia: Teori dan Praktek (ArabicIndonesian Translation: Theory and Practice). Bandung: Humaniora.

Tarigan, Henry Guntur. 1995. Pengajaran Semantik (The Teaching of Semantics). Bandung: Angkasa.

Thaba'i, Sayyid Muhammad Husen. 1997. Al Mizan fi Tafsiril Quran. Beirut: Muassasahul A'lami lil Mathbu'ah.

Thabari, Ibnu Jarir. 2001. Tafsir Thabari: Jamiul Bayan an Ta'wilu Ayyil Quran. Kairo: Darul Hijr.

Wahab, Abdul. 1995. Teori Semantik (Semantic Theory). Surabaya: Airlangga University Press.

Zaenudin, Mamat and Yayan Nurbayan.2007. Pengantar Ilmu Balaghah (Introduction to the Science of Balaghah). Bandung: Refika.

Zamakhsyari. 2009. Al-Kasyaf. Beirut: Darul Fikri.

Zarqani. 1411. Manahilul Irfan fi Ulumil Quran. Mesir: Mustafa al Babi al-Halabi wa Auladih.

Zuhaili. 2009. At-Tafsirul Munir fil Aqidah wasy Syariah wal manhaj. Jilid X. Damaskus: Darul Fikr. 